\title{
EGFRBi-Armed Autologous T Cells
}

National Cancer Institute

\section{Source}

National Cancer Institute. EGFRBi-Armed Autologous T Cells. NCI Thesaurus. Code C71536.

Autologous activated T cells, loaded with a bispecific antibody produced by heteroconjug ation of anti-CD3 and anti-epidermal growth factor receptor (EGFR) monoclonal antibodies, with potential antineoplastic activity. Binding of EGFRBi-armed autologous activated T cells to EGFR-positive tumor cells may result in increased T cellmediated cytotoxicity towards tumor cells expressing EGFR. Arming activated T cells with this bispecific antibody may significantly increase T cell secretion of anti-tumor associated cytokines such as IL2, RANTES, IFN-gamma, and TNF-alpha. 